IRA-International Journal of Management \& Social Sciences

ISSN 2455-2267; Vol.04, Issue 01 (2016)

Institute of Research Advances

http://research-advances.org/index.php/RAJMSS

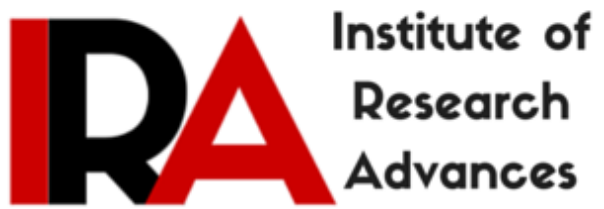

\title{
A Study of Service Quality of Banks in Mumbai
}

\section{Dr Ranjith P V}

Assistant professor,

SIES College of Management Studies, Navi Mumbai, India.

DOI: http://dx.doi.org/10.21013/jmss.v4.n1.p14

\section{How to cite this paper:}

P V, R. (2016). A Study of Service Quality of Banks in Mumbai. IRA-International Journal of Management \& Social Sciences (ISSN 2455-2267), 4(1). doi:http://dx.doi.org/10.21013/jmss.v4.n1.p14

(C) Institute of Research Advances

\section{(c) ) EY-NC}

This works is licensed under a Creative Commons Attribution-Non Commercial 4.0 International License subject to proper citation to the publication source of the work.

Disclaimer: The scholarly papers as reviewed and published by the Institute of Research Advances (IRA) are the views and opinions of their respective authors and are not the views or opinions of the IRA. The IRA disclaims of any harm or loss caused due to the published content to any party. 


\section{ABSTRACT}

Service quality improves customer relationship as far as organizations are concerned. Service quality is about areas like reliability , empathy, assurance etc which if provided in an efficient manner improves customer profitability and organisation's return on investment

The service given generally helps in retaining customers thereby reducing cost of retention and makes customers happy to deal with the organisation. This is required for all service organisations and it is true for banks also. The aspect of service is vital for institutions dealing with money and so the study focuses on the importance of service in customer.

Service quality of different types of banks are studied using tests lime ANOVA and $K$ means cluster analysis to find out the effect on customer satisfaction of different variables and also to find out different customer segments based on their responses.

KEY WORDS-Service Quality, K means cluster, Banking sector, ANOVA

\section{INTRODUCTION}

\section{1 service quality}

Service quality is very important in marketing of services. Firms in service kind of business have to work on quality for improvement of success .High service quality oriented companies achieve better level of client satisfaction and they also retain a sustainable advantage with respect to competitors

Customers and employees of selected branches of these banks were taken for this study. Also the study uses customers (though the number is limited) of ICICI bank also. The banks were selected because they are very important in terms of size and volume of business. The study used 458 samples of customers and more than 100 samples of employees to find out factors which contribute to productivity in a bank.

1. To understand the main factors which influence customer satisfaction in banks.

2. To understand the segments of employees based on responses.

\subsection{LITERAURE REVIEW}

Faruk Anıl Konuk, Filiz Konuk(2013)- The study was aimed at finding relationship between quality of service and costs such as economic and switching in retail banking. Hypothesis which were used were based on Impact of service quality on economic costs, switching costs, impact of economic costs on switching costs, impact of economic costs on loyalty, impact of economic costs on word of mouth intentions, impact of cost of changing banks on word of mouth intentions, impact of switching costs on loyalty and impact of quality of service on loyalty and word of mouth intentions. Questionnaire used demographic profile, usage pattern and likert scale questions on service quality, switching costs, economic costs and behavioral intentions.550 was the sample size. The study concluded that quality of service , financial and costs of changing the bank are the most important reasons for customer loyalty in retail banking context.. The study also concluded that quality of service has direct impact on economic cost and cost of switching and the costs have direct positive effect on both loyalty and word-of-mouth intentions. It also gave the idea that there is a negative relationship between financial costs and switching costs and behavioral intentions. Also service quality, loyalty and word of mouth had positive relationship

Dr Rathee Rupa et al(2014) To Identify Service Quality Gaps in Banking Sector: A Study of Private Banks International Journal of Emerging Research in Management \&Technology Vol3, No.7)2014 The 
study used a sample size of 100 using quota sampling and SERVQUAL scale to find out service quality gaps in private sector banks. The highest gap in the quality areas was found to be in the Reliability and Empathy aspects and the study provides suggestions to solve them.

\subsection{RESEARCH OBJECTIVES}

1. To understand the main factors which influence customer satisfaction in banks.

2. To understand the segments of employees based on responses.

\subsection{RESEARCH METHODOLOGY}

The study is qualitative in nature as it finds out the important parameters why a consumer is doing his transactions but at the same time it attempts to quantify the rating given by consumer to the parameter.

\subsection{SAMPLING DESIGN}

The area from where the sample is selected is called as sampling area.

The sampling area is Mumbai and it is limited to Mumbai as it is not easy to compare between different regional areas owing to time aspect and cost involved.

The major data collection was done on the samples based in Navi Mumbai from the banks concerned ,ie, State Bank of India, Corporation Bank, HDFC,IDBI, Saraswat Bank and some customers of ICICI(ICICI samples are quite less as the administration did not allow customer interaction from the branches).

The employees are also taken from the branches where customers are taken.

Banks which are selected are State Bank of India, Corporation Bank, IDBI, HDFC, Saraswat Bank and ICICI. Customers and Employees of these banks mentioned which are there in the sampling area are taken for the study with more emphasis on public sector banks.

The study has used method of random for consumers and employees. Convenience method was used after deciding the branches and samples were collected from these branches by sitting there and collecting. Whoever was ready to fill the questionnaires were used and there researcher convenience and randomly the customers were taken for the study.

It is not easy to use method of random for consumers because the population is huge but as far as possible samples were collected in such a way that error is limited. Bank employees are taken based by getting permission of the bank management and here also randomness is used to limited extent and more or less sampling was based on readiness of employees to answer the questions in the survey.

The employees were selected in such a way that error is less and as far as possible the study tried to take respondents in a neutral fashion so that all branches are represented equally.

Banks are taken by using convenience of researchers as State bank of India, Corporation, HDFC, IDBI, Saraswat bank etc were easy for the researchers to take and whatever samples which could have been collected from ICICI were taken. 
Bank branches were selected based on randomness. But the number of branches taken for the study for different banks is not the same and whatever possible was taken for the study.

Samples were taken randomly from Navi Mumbai for the purpose of positioning based on convenience of the researcher.

The sample size is 458 in total for customer survey. Bank branches were selected on the basis of convenience of researcher. For each bank approximately 25-30 customers are taken and 2 or 3 branches are taken for each branch. From banks like State Bank of India, Corporation, IDBI etc more samples are taken due to convenience whereas ICICI had fewer samples due to unavailability.

Employee sample size is 112 out of which 68 were from public sector, 11 from private sector(only HDFC as I did not get any replies from ICICI and 33 from Saraswat Co-operative bank ).The number of males and females were taken almost in the same proportion

\subsection{DATA COLLECTION}

This was done using a questionnaire based on questions using combination of banking service quality scale and SERVQUAL. The questions ranged from questions on tangibles to service Employee questions were developed by the researcher himself.

\subsection{DATA ANALYSIS}

The tables shown in the eappendix show the impact of service quality factors on overall satisfaction of consumers. The ANOVA table shows a significance table value of 0.000 which means that independent variables (in this case service quality factors) have strong influence on dependent variable (overall satisfaction).

$\mathrm{R}$ square value is close to $70 \%$ which means that the factors explain $70 \%$ of variance of the dependent variable, overall satisfaction.

The coefficient table shows that price has very big influence on overall satisfaction followed by effectiveness factor and reliability of service. Tangibles have least influence on overall consumer satisfaction of service quality. This analysis gives an idea that these factors are very important for consumer satisfaction and also tells us the importance of giving the services at the right price.

\section{1-SEGMENTATION OF EMPLOYEES}

Using hierarchical clustering (Agglomeration method) we get 4 clusters based on bottom up approach.

The 4 clusters are then analysed using non hierarchical clustering method named as K-Means clustering. From this we get the segments of employees and their view points as far as quality of service is concerned. The main tables and their interpretations are given below.

\section{CLUSTER ANALYSIS}

Cluster for employees. This cluster gives the different segments of employees and the rating given by them for different parameters. 
We can see from cluster analysis that that $4^{\text {th }}$ cluster has maximum employees followed by first cluster . This cluster gives high values close to 7 for each of the parameter except convenient working hours and intrinsic or extrinsic rewards given by the banks.

This means that $4^{\text {th }}$ cluster is very important and parameters which are rated as important by these cluster members will be most crucial for the study and further research in this area has to focus on this.

\section{0- FINDINGS AND CONCLUSION}

The study finds out that consumer satsifaction is very much infleunced by price factor followed by effectiveness factor and reliability of service. Tangibles have least influence on overall consumer satisfaction of service quality. This analysis gives an idea that these factors are very important for consumer satisfaction and also tells us the importance of giving the services at the right price.

Cluster analysis for segmentation finds that amoung the clusters, $4^{\text {th }}$ cluster has maximum employees followed by first cluster. This cluster gives high values close to 7 for most of the parameters which talks about strong agreement except convenient working hours and intrinsic or extrinsic rewards given by the banks.

\section{IMPLICATIONS}

The study will help the banks to find out strategies to attract cutosmers in a better fashion and to devise strategies to meet differt types of customer demands.

\section{REFERENCES}

Dr Ratee Rupa et al To Identify Service Quality Gaps in Banking Sector: A Study of Private Banks International Journal of Emerging Research in Management \&Technology 3(7),2014) 101-106

Konuk, F. A., \& Konuk, F., (2013). The Relationship between Service Quality, Economic and Switching Costs in Retail Banking. Business Systems Review, 2(1),(2014) 1-16. 


\section{APPENDIX}

TABLE 3.1-REGRESSION ANALYSIS (TO FIND IMPACT OF SERVICE QUALITY FACTORS ON OVERALL SATISFACTION)

\begin{tabular}{|c|c|c|c|c|c|c|c|c|c|}
\hline \multicolumn{10}{|c|}{ Model Summary ${ }^{b}$} \\
\hline \multirow[b]{2}{*}{ Model } & \multirow[b]{2}{*}{$\mathrm{R}$} & \multirow[b]{2}{*}{$\begin{array}{l}\mathrm{R} \\
\text { Square }\end{array}$} & \multirow[b]{2}{*}{$\begin{array}{l}\text { Adjusted } \\
\mathrm{R} \\
\text { Square }\end{array}$} & \multirow{2}{*}{\begin{tabular}{|l} 
Std. \\
Error of \\
the \\
Estimate
\end{tabular}} & \multicolumn{5}{|c|}{ Change Statistics } \\
\hline & & & & & $\begin{array}{l}\mathrm{R} \\
\text { Square } \\
\text { Change }\end{array}$ & $\begin{array}{l}\mathrm{F} \\
\text { Change }\end{array}$ & df1 & $\mathrm{df} 2$ & $\begin{array}{l}\text { Sig. F } \\
\text { Change }\end{array}$ \\
\hline 1 & $.836^{\mathrm{a}}$ & .699 & .693 & .67683 & .699 & 127.689 & 5 & 275 & .000 \\
\hline
\end{tabular}

a. Predictors: (Constant), ACCESS, TANGIBLES, PRICE, RELIABILITY, EFFECTIVENESS

b. Dependent Variable: OVERALL SERVICES GIVEN TO CUSTOMERS IS GOOD

TABLE 3.2-ANOVA

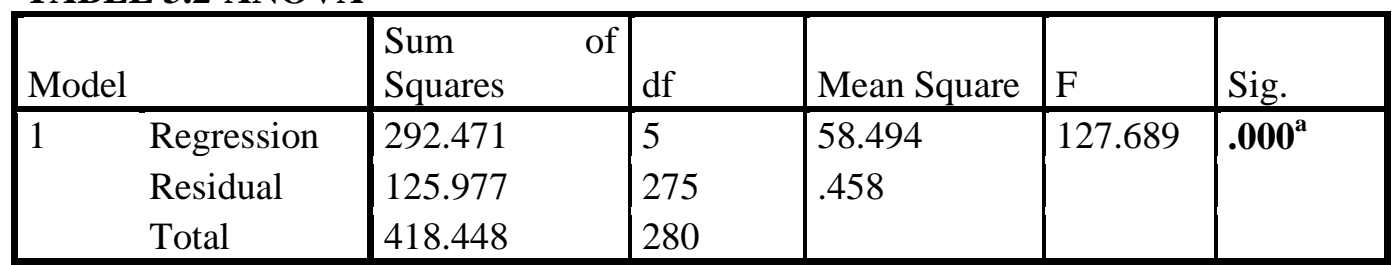

a. Predictors: (Constant), ACCESS, TANGIBLES, PRICE, RELIABILITY, EFFECTIVENESS

b. Dependent Variable: OVERALL SERVICES GIVEN TO CUSTOMERS IS GOOD

TABLE 3.3-COEEFICIENT TABLE IN REGRESSIONCoefficients ${ }^{\text {a }}$

\begin{tabular}{|c|c|c|c|c|c|c|}
\hline \multirow{2}{*}{\multicolumn{2}{|c|}{ Model }} & \multicolumn{2}{|c|}{$\begin{array}{l}\text { Unstandardized } \\
\text { Coefficients }\end{array}$} & \multirow{2}{*}{$\begin{array}{l}\text { Standardized } \\
\text { Coefficients } \\
\text { Beta }\end{array}$} & \multirow[b]{2}{*}{$\mathrm{t}$} & \multirow[b]{2}{*}{ Sig. } \\
\hline & & $\mathrm{B}$ & Std. Error & & & \\
\hline \multirow[t]{6}{*}{1} & (Constant) & .436 & .245 & & 1.775 & .077 \\
\hline & TANGIBLES & .026 & .053 & .022 & .487 & .627 \\
\hline & EFFECTIVENESS & .185 & .071 & .165 & 2.621 & .009 \\
\hline & PRICE & .550 & .051 & .549 & 10.866 & .000 \\
\hline & RELIABILITY & .165 & .065 & .149 & 2.547 & .011 \\
\hline & ACCESS & .054 & .045 & .049 & 1.208 & .228 \\
\hline
\end{tabular}

a. Dependent Variable: OVERALL SERVICES GIVEN TO CUSTOMERS IS GOOD 
TABLE 3.4-Final Cluster Centers

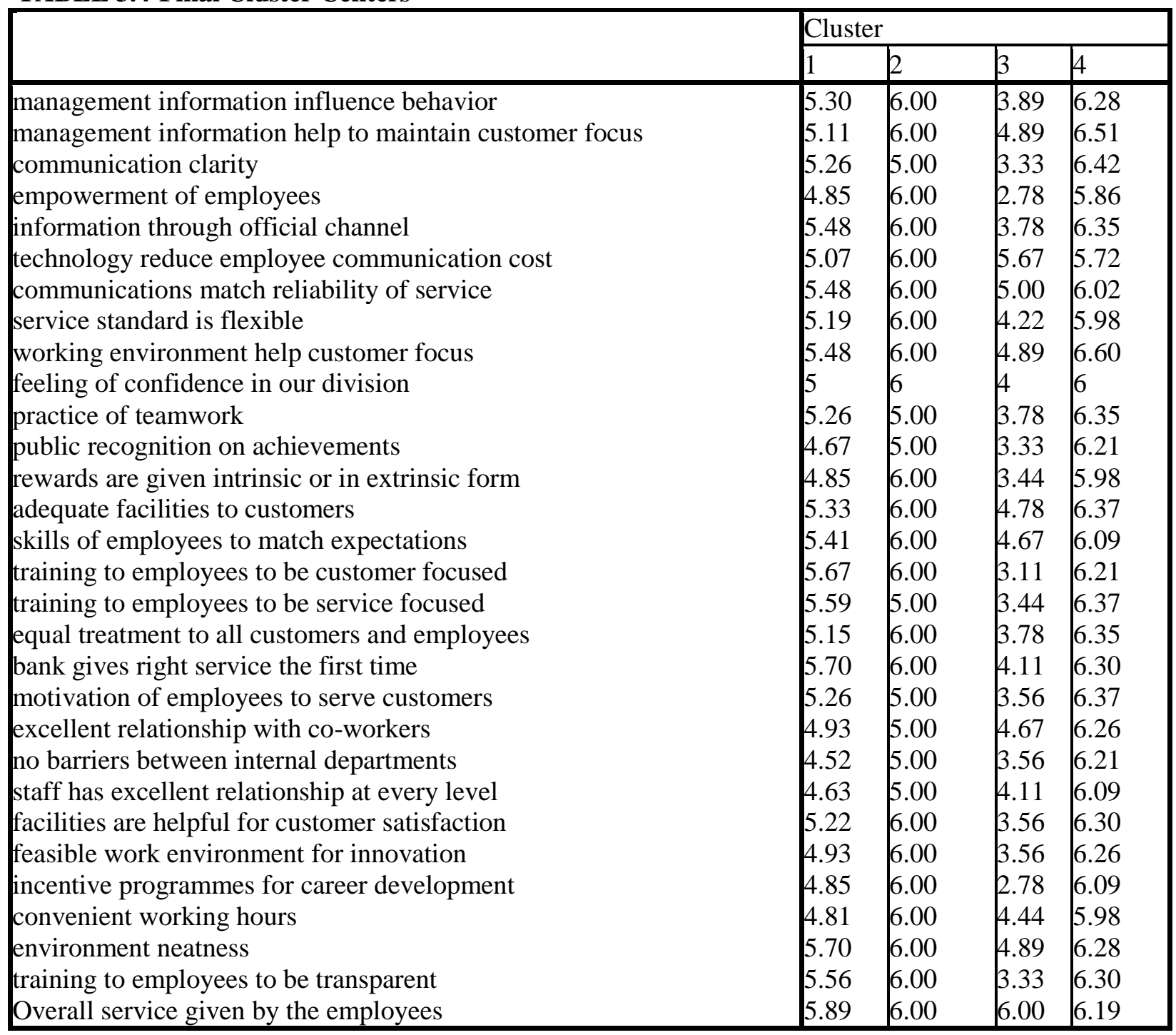

TABLE 3.5-Number of cases in each Cluster

\begin{tabular}{|ll|l|}
\hline cluster & 1 & 27.000 \\
& 2 & 1.000 \\
& 3 & 9.000 \\
& 4 & 43.000 \\
\hline
\end{tabular}

